\title{
YOUTH NETWORKS ON FACEBOOK AND TWITTER DURING THE 2015 GENERAL ELECTIONS IN NIGERIA
}

\section{Ayodeji Anthony Aduloju}

Ayodeji Anthony Aduloju is a doctoral candidate in the Department of International Relations at Obafemi Awolowo University, Ile-Ife, Nigeria. email: adulojutony@gmail.com

\begin{abstract}
In this study I used secondary sources of data to examine how Nigerian youth formed socio-political networks on social media platforms Facebook and Twitter, and how these media influenced the 2015 general elections. I purposively selected four Facebook accounts and four Twitter handles of politicians, political parties and news agencies. The Facebook accounts were those of Goodluck Jonathan, Muhammadu Buhari, Channels Television and Sahara Reporters. The Twitter handles were those of Femi Fani-Kayode, Doyin Okupe, Rueben Abati and Nasir El-Rufai. The Facebook accounts and Twitter handles were selected based on their number of followers and likes. I performed an archival study of posts and tweets between 1 January 2015, when the election campaign started, and 30 April 2015, when all election results were declared by INEC. I also purposively selected five posts and tweets each from the Facebook accounts and Twitter handles, from among myriad posts and tweets, according to which had the highest number of replies on political issues from 1 January 2015. All data obtained were analysed using descriptive analyses. The findings showed that not all followers of political parties and politicians on Facebook and Twitter are their supporters. Moreover the platforms raised the consciousness of Nigerian youth during the 2015 elections in the area of constructive and destructive arguments directly with politicians, which gave birth to new socio-political movements of followers and antagonists. The results also showed that youth networks helped to shape the 2015 elections in terms of exposing and preventing insecurity and fraud. I concluded that social media play a potent role in galvanising Nigerian youth for political discourse, conscientisation and education, which in turn can facilitate effective transformation of electoral processes in Nigeria.
\end{abstract}

Keywords: electoral violence, youth restiveness, political propaganda, democracy, social media 


\section{INTRODUCTION}

Periodic elections have become recurrent in Nigeria, following the successful historic transition of the country from military despotic rule to democracy in 1999. Although conflicts, rigging, and low turnout by electorates have marred past elections, the 2015 general elections were a watershed in Nigeria's democratic process, owing to the rousing commendation the outcome drew from domestic and international communities. The main concern of these communities was the successful transition from one democratic administration to another, which was accomplished with consummate ease. Also this was the first time since 1999 (when the military handed over power to civilians) that the opposition had a realistic chance of dislodging the ruling party (Adibe 2015).

The 2015 general election happened when Nigeria was caught up in the dilemma of opportunity and challenge, more than at any other point since the country's first decade of independence. Hate speech and soapbox rhetoric were heating up the social and political system. The mandate of the electorate carries a high stake for governance, security, and the economy (Thurston 2015). These stakes largely defined the interests of the international community, which was visible in its ultra-careful support for the successful conduct of the election. Hopes were high that the most populous black nation in the world would once again conduct an election that would mean development, unity and peace - not only for Nigeria but for Africa at large. This aspiration was noticeable in visits by the United States' Secretary of State and other world leaders to the two main contenders for the apex executive office in Nigeria, Goodluck Jonathan and Muhammadu Buhari, to obtain their views on the conduct of violence-free elections. This clearly showed the role of the international community as a neutral actor.

Within the domestic community, the election bred a large socio-political movement among Nigeria's politically literate. Civil society groups such as the Civil Liberties Organization; Campaign for Democracy; Nigerian Union of Journalists; Centre for Democracy and Development; Nigeria Labour Congress; Transition Monitoring Group; Electoral Reform Network; National Coalition on Affirmative Action; Gender, Electoral and Constitutional Reform; and Committee for the Defence of Human Rights amongst others (Uadiale 2011; Omede \& Bakare 2014) all pledged their usual roles. Omede and Bakare (2014) believe these roles are sine qua non for the sustenance of a nation's development, especially during elections. Nonetheless, the general elections resulted in an unusual or new movement by Nigerian youth on social media platforms, especially Facebook and Twitter.

Until the 2015 elections, the participation of youth in Nigeria's electoral processes was mediocre owing to their being resigned to the notion that the 
electorate's vote does not count. In addition, studies on the participation of youth in elections in Nigeria have identified the high rate of youth illiteracy, deprivation and unemployment as factors that led youth to be involved in vices such as political thuggery, violence, assassination, intimidation, harassment and election rigging (Obi 2006; Inokoba \& Maliki 2011; Bamgbose 2012; Abdullahi 2013; Halliru 2013; Aduloju \& Pratt 2015; Fasakin 2015). Surprisingly, youth in Nigeria redefined the 2015 general elections through the social media platforms of Facebook and Twitter. These left an indelible mark on the electoral system, and at the same time carved out new directions for elections in the country.

\section{YOUTH ON FACEBOOK AND TWITTER IN NIGERIA}

Social media represent an internet-based platform, which shares most if not all of the following characteristics: participation, openness, conversation, community and connectedness (Mayfield 2006). It is one of the driving forces of globalisation and has validated the statement that the world is a global village. The main characteristics of social media, as highlighted in the definition above, make these platforms useful not only to the business world (owing to its tendencies of making millionaires and billionaires) but also to politics, religion, academia and all other walks of life. The notion of participation and openness gives an opportunity to every individual - regardless of age, gender, race, background and social status. If there is anything humans desire most it is the opportunity to belong and have access, which the notion of participation and openness affords. With regard to other characteristics in the definition above, the notion of conversation, community and connectedness speaks to the human need for identity. People always want to communicate, to listen and to be heard. Social media platforms give people this sense of identity.

According to Mayfield (2006), the concepts of participation, openness, conversation, community and connectedness corroborate the study by Pescosolido (2007, pp. 208-211). Pescosolido works with the sociology of social networks, and believes that the sociological nature of humans is to form ties to maintain contact. She also posits that relationships or ties are the fundamental building blocks of human experience, mapping the connections that individuals have to one another (Pescosolido 1991). Consequently, from the sociological perspective, social media platforms are extensions of human nature: to maintain contact with one another. To maintain this contact, humans over time invented social media platforms such as Facebook, Twitter, Blog, WhatsApp, Myspace, LinkedIn, YouTube and Flickr.

In a survey carried out by Pew Research in 2013, Facebook and Twitter were the predominant players in social media network platforms (Duggan \& Smith 2013), though Facebook is the most popular and has the highest number of users 
across the globe. The Pew Research survey of 2015 showed that $71 \%$ of internet users use Facebook, while a substantial number of users also use Twitter (Duggan et al. 2015). The reason for this is fairly simple. The platforms afford individual or groups the opportunity to access and exchange information, share comments, and engage in conversations.

In Nigeria, the popularity of Facebook and Twitter has grown over time. Nigeria, with an estimated population of over 167 million, is at the forefront of internet users in Africa. According to Seal-World (2014), internet users in Nigeria are frequently on social media platforms including Facebook and Twitter, and the country is thought to have the most Facebook and Twitter users in Africa (Business Day 2013). A study by the Business Day Research and Intelligence Unit showed that Facebook and Twitter are Nigeria's most active social media platforms.

If the above trends are accepted as a given, it could be inferred that social media is largely the domain of the youth. If one considers the features Mayfield highlighted in his definition of social media (participation, openness, conversation, community and connectedness), one may deduce that the social mentality of youth is driven by these features. There is no doubt that young adults live in a world of their own making and social media has helped them to create that society. Evidently today youth's quest to socialise with one another has led to this era being dubbed the 'jet age', 'social-media generation' and 'Net-generation'. Their voracious appetite for acquiring information and sharing it shows the influence and relevance of social media, which Facebook and Twitter platforms in particular offer.

According to the United Nations Population Fund, 'half of the world's population of 6.3 billion people are under the age of 25.' On Facebook and Twitter the youth comprises 70\% of active users (Ogunlesi 2013, pp. 21-22). The Nigerian National Youth Policy (2001) defines youth as all young persons aged between 18 and 35 years who are citizens of the Federal Republic of Nigeria. Ogunlesi (2013) calculated a breakdown of youth statistics and reported that $75 \%$ of Nigeria's population is under 35 years, with about 50\% of them being 18 years old in 2013 (ibid, p. 23). Consequently, Nigerian youth are conspicuous among Facebook and Twitter users in the country. It is not surprising that this digital age belongs to them and their contemporaries across the world.

On Facebook, young people are not restricted in sharing information or pictures, or in choosing friends or liking pages where they can discuss and follow their curiosity. Twitter similarly affords them the opportunity to share pictures, send brief information in headline form (popularly known as a 'tweet'), have followers and follow pages of their choice. The ease of access to own an account on both Facebook and Twitter platforms permits youth to interact, socialise and connect. From this they form networks based on circumstances and dictates of their environment. My study and observations showed that it is common, on these 
platforms, for young people to review or raise arguments about the lifestyles of celebrities in the entertainment, fashion and sport industries - such as musicians, actors and actresses, and sports men or women. Recently, Facebook and Twitter have influenced young people's mindset on political issues that have over time impacted on Nigeria's political landscape. Generally, circumstances and events in the social environment dictate the use of Facebook and Twitter by the youth.

\section{YOUTH, FACEBOOK AND TWITTER IN THE 2015 GENERAL ELECTIONS}

In preparation for the 2015 general elections in Nigeria, Facebook and Twitter played myriad roles, especially in the areas of electioneering, political campaigns, mobilisation and enlightenment of the electorate. Political parties, politicians and news agencies used social media to disseminate information and to solicit support and sympathy from the general population who constituted part of the electorate. During the period of elections, notably on Facebook and Twitter, hashtags of trending news and events were created for easy access to news and information. For instance, news agencies, civil societies and the Independent National Electoral Commission (INEC) made use of the hashtag \#NigeriaDecides to categorise information. The electoral umpire, INEC, constantly used the hashtag to disseminate information on the elections through social media platforms. Politicians and political parties also explored this means to pursue their ambitions and to propagate their names in order to gain popularity among Facebook and Twitter followers.

According to Gambo (2015), voters aged 18 to 34 make up 65\% of the voting population in Nigeria. Individuals within this age bracket also constitute the largest Facebook and Twitter population in Nigeria. Hence young people in the country made use of Facebook and Twitter during the general elections. The power with which internet literacy equips the youth was effectively deployed in persuading stakeholders during the election to use social media platforms. A substantial number of politicians and political parties have Facebook and Twitter accounts where they outlined their manifestos and motives for vying for political positions. Through the inquisitive and voracious nature of young people, they subjected the manifestos and motives of politicians and political parties to interrogation. They mandated political parties and their candidates contesting elective positions to clarify their various manifestos.

\section{RESEARCH METHODOLOGY}

This section discusses the data used for this study, including the method of data collection, sampling techniques and data analysis. As already explained, the 
research focused on Nigerian youth and the socio-political networks that were formed on Facebook and Twitter around the time of the 2015 general elections.

\section{Study area}

The study area was Nigeria and the social media platforms Facebook and Twitter. Nigeria is located in the western region of Africa. Facebook and Twitter define the borderless contiguity of the world, and have equally been part of the main propellants of globalisation and technological revolution of the current era. The importance of these topics to the study was not only the large concentration of youth; they also served as defined locations of abode for Nigerian youths during the 2015 general elections.

Nigeria has had challenging times transiting from one democratic regime to another. During the period of the 2015 elections, the youth population - both on social media and within the country - formed a movement to press for free and fair elections, to campaign and support the candidates and parties of their choice, and to create awareness and advocacy on issues that troubled the elections.

\section{Study population}

'Population' denotes a large group from which a study sample is taken. It also entails the subjects a study seeks to investigate (Ary, Jacobs \& Razavieh 1972). To ensure that reliable and adequate data are obtained to investigate the research problem, the researcher must locate a population sample that is adequate for the study. It is important that such a sample gives a true representation of the population under study. The population considered in this study comprised youths who were followers of selected Facebook and Twitter accounts. Youth are the largest active population on the selected social media platforms examined in this study, according to the findings of a pilot survey conducted in the first part of the research. Ogunlesi (2013) opined that Nigerian youth constitute 70\% of active social media users in the country.

I estimated the total number of youth based on their responses to posts and tweets. I checked their profiles to be sure that they were young people, and if I could not be sure of the user's age then I ignored their comments. Tables 1 and 2 show the demographic representations of the social media accounts I selected. Based on the total number of likes and followers, I agreed with the estimate of $70 \%$ youth among the accounts I studied. 
Table 1

Facebook population of politicians and news agencies selected for the study

\begin{tabular}{|l|c|c|}
\hline $\begin{array}{l}\text { Official name of } \\
\text { Facebook account }\end{array}$ & $\begin{array}{l}\text { Total number of likes (P, } \\
\text { population) }\end{array}$ & $\begin{array}{l}\text { Estimated number of youth on } \\
\text { account } \mathbf{( 7 0 \%} \text { of P ) }\end{array}$ \\
\hline Goodluck Jonathan & $1,864,143$ & $1,304,900$ \\
\hline Muhammadu Buhari & 121,949 & 85,364 \\
\hline Channels Television & 455,278 & 318,695 \\
\hline Sahara Reporters & $1,631,565$ & $1,142,096$ \\
\hline
\end{tabular}

Author's survey, 2015

Table 2

Twitter population of politicians and political parties selected for the study

\begin{tabular}{|l|c|c|}
\hline $\begin{array}{l}\text { Official name of Twitter } \\
\text { account }\end{array}$ & $\begin{array}{l}\text { Total number of } \\
\text { followers (P) }\end{array}$ & $\begin{array}{l}\text { Estimated number of youth on } \\
\text { account (70\% of P) }\end{array}$ \\
\hline Doyin Okupe & 69,867 & 48,907 \\
\hline Rueben Abati & 251,121 & 175,785 \\
\hline Nasiru El- Rufai & 579,249 & 405,474 \\
\hline Femi Fani-Kayode & 146,060 & 102,242 \\
\hline
\end{tabular}

Author's survey, 2015

\section{Sample size and selection}

In this study I solely used secondary data, obtained through purposively selected posts on specific Facebook and Twitter accounts during the 2015 general elections. Four Facebook accounts and six Twitter handles of politicians, political parties and news agencies were chosen. The Facebook accounts were those of Goodluck Jonathan, Muhammadu Buhari, Channels Television and Sahara Reporters. The Twitter handles selected were those of Femi Fani-Kayode, Doyin Okupe, Rueben Abati and Nasiru El-Rufai. The selection of Facebook and Twitter accounts of these individuals was informed by their popularity (number of youth followers and likes on their Facebook and Twitter accounts), the sensitivity of their posts, and how youths responded to them during the general elections.

\section{DATA PRESENTATION AND ANALYSIS}

For the purpose of this study I analysed $70 \%$ of all comments and replies on the selected posts made by youth, shown in Tables 3 to 10 below. This was based 
on the premise that youth constitute $75 \%$ of the total population in Nigeria and account for $70 \%$ of active social media users in the country (Ogunlesi 2013). According to Gambo (2015), 65\% of voters in Nigeria are young people. Tables 3 to 10 also show the dates of posts and tweets examined in this study, as well as the total comments provided, and the number of comments estimated to have been made by the youth (calculated as $70 \%$ of the total comments). In addition, the first 200 comments, or the first 50 comments if the total comments were 199 or less, were analysed. Where posts received fewer than 50 comments these were also analysed. Simple descriptive analysis was used to analyse the archival data from the selected Facebook and Twitter accounts, with posts and tweets being quoted and discussed.

Table 3

Selected posts by Goodluck Jonathan

\begin{tabular}{|l|l|c|c|c|}
\hline Jonathan's Posts & Date & $\begin{array}{l}\text { Total } \\
\text { number } \\
\text { of } \\
\text { comments } \\
\text { (C) }\end{array}$ & $\begin{array}{l}\text { Estimated } \\
\text { number of } \\
\text { comments } \\
\text { by youth } \\
\text { (70\% of C) }\end{array}$ \\
\hline $\mathbf{1}$ & $\begin{array}{l}\text { 'Earlier today, I participated in the Presidential } \\
\text { Debate organized by the Nigeria Elections } \\
\text { Debate Group (NEDG). I am convinced that } \\
\text { anyone who desires to lead Nigerians must } \\
\text { first be prepared to address issues raised by } \\
\text { Nigerians. I also believe we must encourage a } \\
\text { culture of debate and conversation to grow our } \\
\text { democracy. GEJ.' }\end{array}$ & $\begin{array}{l}\text { March 22, } \\
\text { 2015 }\end{array}$ & 10,454 & 7,318 \\
\hline $\mathbf{2}$ & $\begin{array}{l}\text { 'When I first assumed office as President of } \\
\text { Nigeria on the 6th of May, 2010, I promised } \\
\text { Nigerians that elections under my watch will be } \\
\text { free, fair and credible. Since then, I have taken } \\
\text { deliberate steps to ensure that that promise } \\
\text { translates to reality. Gone are the days of do } \\
\text { or die elections. Gone are the days when the } \\
\text { world looked down at our elections. Together, } \\
\text { we have ensured that elections in Nigeria are a } \\
\text { manifestation of one man one vote, one woman } \\
\text { one vote and one youth one vote. You can } \\
\text { be sure that as long as Jonathan is President, } \\
\text { your votes will count and be counted. I have } \\
\text { directed our security services to ensure that } \\
\text { your right to vote is fully facilitated. So have no } \\
\text { fear on Election Day. Come out and vote for the } \\
\text { candidates of your choice. Remember, we are } \\
\text { all brothers and sisters from the womb of one } \\
\text { Nigeria and as long as Nigeria wins, we have all } \\
\text { won. GEJ.' }\end{array}$ & March 25, & 8,571 & 6,000 \\
\hline
\end{tabular}




\begin{tabular}{|c|c|c|c|c|}
\hline 3 & $\begin{array}{l}\text { 'My dear friends on Facebook, } \\
\text { As we celebrate Easter and the resurrection of } \\
\text { Jesus Christ, I want to celebrate all Nigerians for } \\
\text { keeping faith with democracy which is the only } \\
\text { vehicle for the continuous growth and stability } \\
\text { of our dear nation. Easter is the culmination } \\
\text { of the Lenten season, a time to imbibe Christ's } \\
\text { teachings of reconciliation with God and } \\
\text { each other. This year's celebration of Easter is } \\
\text { taking place at a period of very critical national } \\
\text { choices and decisions, during which we must } \\
\text { all be prepared and willing to make sacrifices } \\
\text { for greater unity, peace, political stability and } \\
\text { progress in our beloved country. As a nation, } \\
\text { we must accept that the Presidential elections } \\
\text { are behind us and reconcile our differences as } \\
\text { children born from the womb of one mother, } \\
\text { Nigeria. I am confident that we will do this. } \\
\text { Happy Easter and may God bless Nigeria. GEJ.' }\end{array}$ & $\begin{array}{l}\text { April 4, } \\
2015\end{array}$ & 40,784 & 28,549 \\
\hline 4 & $\begin{array}{l}\text { 'We waited patiently to vote in these elections, } \\
\text { now I want to urge all Nigerians to also wait } \\
\text { patiently for the Independent National Electoral } \\
\text { Commission, INEC, to collate and announce } \\
\text { results. We must ensure that we do not get } \\
\text { involved in acts that breach our peaceful co- } \\
\text { existence that we patriotically demonstrated } \\
\text { during the elections. May God bless Nigeria. } \\
\text { GEJ.' }\end{array}$ & $\begin{array}{l}\text { March 29, } \\
2015\end{array}$ & 14,545 & 10,182 \\
\hline 5 & $\begin{array}{l}\text { 'Today, I visited the Northeastern part of our } \\
\text { Country. I was with our soldiers and interacted } \\
\text { with the officers and men of our gallant armed } \\
\text { forces. I am very proud of their patriotism and } \\
\text { the valour they have demonstrated as they } \\
\text { fight to protect our citizens and our territorial } \\
\text { integrity. The sight of Nigerian citizens } \\
\text { returning to towns once occupied by insurgents } \\
\text { was most fulfilling. May God continue to bless } \\
\text { Nigeria. GEJ' }\end{array}$ & $\begin{array}{l}\text { February } \\
27,2015\end{array}$ & 13,835 & 9,685 \\
\hline
\end{tabular}

(Author's survey, 2015)

Table 3 shows the five selected posts, the dates they were posted, the total number of comments, and the estimated number of youth's comments. I studied the first 200 replies by youth to the posts quoted above, and found an estimated $80 \%$ in the first post that praised the personality of Goodluck Jonathan for attending the presidential debate, from which his major opponent, Muhammadu Buhari, had absented himself. The remaining 20\% were indifferent about Muhammadu Buhari attending the debate and needed explanation on certain issues (corruption, unemployment and insecurity) in the country. 
The second post came a few days before the election and it sensitized the people on how to make their votes count. In the first 200 comments that followed this post, $55 \%$ of them were campaigning and affirming their support for Jonathan, while $45 \%$ were against him and rather campaigned for his opponent, Muhammadu Buhari - even on Jonathan's own Facebook page. The third post was made after the election result was declared by INEC. It attracted a lot of sympathetic comments from the youth. It was an Easter message from the president, and over $99 \%$ of the first 200 comments expressed sympathy and praise for President Jonathan for conceding defeat to his opponent in good faith. For the fourth post, the first 200 comments showed that $50 \%$ supported Jonathan and were confident that he would win the election, while the other $50 \%$ anticipated victory for the opposition candidate. Lastly, the fifth post enjoyed commendation in comments that followed, with $80 \%$ praising Jonathan's visit to the troubled Northeastern Nigeria, while $20 \%$ commented otherwise.

In studying the comments following each post, I discovered there were also replies beneath some comments. In these replies, abusive comments and complimentary remarks were made by those who were either against or in support of the posts, respectively. Some of the comments have about 500 replies in addition to the comments on the post. This created a sub-network of pros and cons.

Table 4

Selected posts by Muhammadu Buhari

\begin{tabular}{|c|c|c|c|c|}
\hline $\mathrm{S} / \mathrm{N}$ & Buhari's Post & Date & $\begin{array}{l}\text { Total } \\
\text { number of } \\
\text { comments } \\
\text { (C) }\end{array}$ & $\begin{array}{l}\text { Estimated } \\
\text { number of } \\
\text { comments } \\
\text { by youth } \\
(70 \% \text { of } C)\end{array}$ \\
\hline 1 & $\begin{array}{l}\text { Many thanks to my supporters for the } \\
\text { \#BabaWhileYouWereGone updates thisweekend. } \\
\text { They have made my day \#GladToBeBack I am } \\
\text { heartened to see that good humour and resolve } \\
\text { rest deep in the hearts of those who seek Change } \\
\text { Despite the sticks and stones, we choose to } \\
\text { remain focused and direct our energies into } \\
\text { forging a bright future The troubling issues that } \\
\text { face the nation continue unabated - plummeting } \\
\text { power production \& naira value, petrol queues } \\
\text { Our collective strength, our ability to forge ahead } \\
\text { in the toughest of times is what will allow us to } \\
\text { restore Nigeria I am \#GladToBeBack to make the } \\
\text { Change needed Pick up your PVC by } 22 \text { March } \\
\text { and vote for APC on } 28 \text { March \& } 11 \text { April. Let's } \\
\text { bring the Change Nigeria needs } \\
\text { - GMB }\end{array}$ & $\begin{array}{l}\text { March 9, } \\
2015\end{array}$ & 294 & 206 \\
\hline
\end{tabular}




\begin{tabular}{|c|c|c|c|c|}
\hline 2 & $\begin{array}{l}\text { Nothing can stop a change whose time has } \\
\text { come \#ThingsWILLChange }\end{array}$ & $\begin{array}{l}\text { February } \\
18,2015\end{array}$ & 136 & 95 \\
\hline 3 & $\begin{array}{l}\text { 'The countless man hours that will be spent at } \\
\text { petrol stations today, will reduce our productivity } \\
\text { as a nation. This should not be so. } \\
\text { In my time as NNPC chairman and Petroleum } \\
\text { Minister in the late } 70 \text { s, } 2 \text { of our } 4 \text { refineries were } \\
\text { built, and domestic consumption catered for. } \\
\text { But over the last several years our refineries have } \\
\text { declined, and we are at the mercy of imports. } \\
\text { We must reject a system that has turned one of } \\
\text { world's largest crude exporters into an importer } \\
\text { of petrol. Things must change. } \\
\text { - GMB' }\end{array}$ & $\begin{array}{l}\text { March 4, } \\
2015\end{array}$ & 386 & 270 \\
\hline 4 & 'A step towards the journey begins.' & $\begin{array}{l}\text { March } \\
28,2015\end{array}$ & 351 & 246 \\
\hline 5 & $\begin{array}{l}\text { Happy Valentine's Day everyone! Keep } \\
\text { believing. } \\
\text { Today, there is an outpouring of love for Nigeria. } \\
\text { We are inspired! \#ThingsWILLChange \#FeBuhari }\end{array}$ & $\begin{array}{l}\text { February } \\
14,2015\end{array}$ & 123 & 86 \\
\hline
\end{tabular}

(Author's survey, 2015)

As shown in Table 4, I analysed five selected posts by Muhammadu Buhari, the main opponent during the 2015 general election. With an estimated 206 youth comments on the first post, some $15 \%$ among the first 200 which I studied doubted the authenticity that Buhari manages his own Facebook account, while 85\% of comments expressed support for his candidature through the use of photos. The second post was photographic with a short message and a hashtag for change. About $30 \%$ of the comments below it were campaigning for continuity of the opposition, and about $70 \%$ were in support of the post, with photographic comments to affirm the message posted. In the third post, about $40 \%$ of the comments doubted Buhari's intellectual capability to lead Nigeria. A close look at Buhari's post indicated an error of either topographical or grammatical nature, which gave opponents more grounds to discredit and dismiss Buhari's candidature for the presidency of Nigeria. However, $60 \%$ of comments defended and campaigned for Buhari. The fourth post was sent at the time Buhari cast his vote. Attached with the short message was a picture of Buhari being accredited to be able to vote. In the first 200 comments studied, about $98 \%$ were optimistic that Buhari would win the presidential election, while the remaining $2 \%$ were not. It was difficult to notice the comments of the opposing $2 \%$ because of the confidence displayed by the $98 \%$. 
The fifth post in Table 4 was sent on 14 February, Valentine's Day, and the message was for youth to enjoy the day. About $80 \%$ of comments that supported Buhari did not speak to the message, rather campaigning for him. Of those commentators who were against Buhari, about $20 \%$ were skeptical of the content of the message and wondered if Buhari believed in Valentine's Day. (I mentioned earlier that there was also doubt expressed in the comments to the first post, about the authenticity of Buhari's management of his Facebook account.) The findings in Table 4 show that the youth were able to question the originality and authenticity of Buhari's ownership of the account.

Table 5

Selected news headline posts by Channels Television

\begin{tabular}{|l|l|l|c|c|}
\hline & Channels Television headline post & Date & $\begin{array}{l}\text { Total } \\
\text { number } \\
\text { of } \\
\text { comments } \\
\text { (C) }\end{array}$ & $\begin{array}{l}\text { Estimated } \\
\text { number of } \\
\text { comments } \\
\text { by youth } \\
\text { (70\% of C) }\end{array}$ \\
\hline $\mathbf{1}$ & $\begin{array}{l}\text { LIVE: APC Presidential Candidate @ } \\
\text { ThisIsBuhari Meets Organised Private } \\
\text { Sector In Lagos. Tune in @ channelstv via m. } \\
\text { channelstv.com }\end{array}$ & $\begin{array}{l}\text { February 2, } \\
2015\end{array}$ & 40 & 28 \\
\hline $\mathbf{2}$ & $\begin{array}{l}\text { MUST WATCH! } \\
\text { Former Super Eagles player, Joseph Yobo } \\
\text { speaks in support of Goodluck Jonathan, as } \\
\text { he campaigns for a second term in office. For } \\
\text { more information log on to http://www. } \\
\text { channelstv.com }\end{array}$ & $\begin{array}{l}\text { January 8, } \\
2015\end{array}$ & 197 & 138 \\
\hline $\mathbf{3}$ & $\begin{array}{l}\text { President Goodluck Jonathan, has met with } \\
\text { state Governors elected on the platform of the } \\
\text { PDP to strategise on how to win in the March } \\
\text { 28 and April 11 general elections. }\end{array}$ & $\begin{array}{l}\text { March 3, } \\
2015\end{array}$ & 57 & 40 \\
\hline $\mathbf{4}$ & $\begin{array}{l}\text { The Chairman of INEC, Prof Attahiru Jega, is } \\
\text { expected to appear before the Senate today to } \\
\text { explain reasons for the postponement of the } \\
\text { general elections by six weeks. }\end{array}$ & $\begin{array}{l}\text { February } \\
19,2015\end{array}$ & 14 & 213 \\
\hline $\mathbf{5}$ & $\begin{array}{l}\text { The Peoples' Democratic Party Presidential } \\
\text { Campaign Organization (PDPPCO) has } \\
\text { alleged plans to frustrate supplies of petrol } \\
\text { to fuel stations as an initiative from the } \\
\text { opposition (APC). }\end{array}$ & $\begin{array}{l}\text { March 2, } \\
2015\end{array}$ & 304 & 10 \\
\hline
\end{tabular}

(Author's survey, 2015) 
Table 5 comprises selected posts by Channels Television. The first post was about a live presidential campaign organised by the All Progressives Congress for Buhari. The post intended to attract an audience to watch live campaign rallies on the internet, wherever they might be. Surprisingly, some of the comments that followed interrogated the absence of Buhari at the presidential debate prior to the programme aired live on Channels TV. Of these, 55\% of comments doubted his credentials, eligibility and fitness for the office of President of Nigeria, while $45 \%$ were supportive of his actions and therefore campaigned for him. This post sparked the use of foul language against one another. The second post was a video attached with a short statement by Joseph Yobo, former captain of the Nigerian national football team, the Super Eagles. In the statement he claimed that Jonathan helped them win the African Cup of Nations hosted by South Africa in 2013. Of the comments that followed, $96 \%$ contained abusive statements about the former captain of the Super Eagles and also faulted technical and professional input in the Peoples' Democratic Party's campaign. Roughly 4\% of comments campaigned for Jonathan and justified Yobo's statement to exonerate him from criticism.

The third post (see Table 5) stated that Jonathan had met with PDP state governors to strategise on how to win the elections. Of the comments that followed, $85 \%$ were directed at faulting and doubting the competence of the adopted strategy through photographic comments. Another 15\% commented on their confidence that PDP would eventually gain a landslide victory at the polls. I noticed that some comments attracted replies because of their sensitivity. Some replies were full of vile language as counter-reactions in response to the comments made to the post. Through this the study revealed a trend among youth to bully each other on social media.

The fourth post was a headline about the summons of INEC Chairman by Nigeria's Senate to respond to questions raised, which centred on the postponement of the general elections scheduled earlier. Almost $100 \%$ of comments on this post interrogated the Senate's pretence of not having enough information about the postponement beforehand. A substantial number of comments affirmed support for INEC and expressed trust in the Commission's capability to conduct free and fair elections in Nigeria. The fifth comment stated the claims of the Peoples' Democratic Party Presidential Campaign Organization (PDPPCO) that APC had masterminded a fuel scarcity in the country at the time. About $98 \%$ of the comments that followed criticised the stand of PDPPCO on the issue of fuel scarcity. The remaining $2 \%$ did not comment on the statement but rather campaigned for Jonathan. 
Table 6

Selected news headline posts by Sahara Reporters.

\begin{tabular}{|l|l|l|l|r|}
\hline & Sahara Reporters headline post & Date & $\begin{array}{l}\text { Total } \\
\text { number of } \\
\text { comments } \\
\text { (C) }\end{array}$ & $\begin{array}{l}\text { Estimated } \\
\text { number of } \\
\text { comments } \\
\text { by youth } \\
\text { (70\% of C) }\end{array}$ \\
\hline $\mathbf{1}$ & $\begin{array}{l}\text { PDP Governors Blame National } \\
\text { Chairman, Muazu, For Electoral Defeat, } \\
\text { Demand Ouster Of National Working } \\
\text { Committee. }\end{array}$ & $\begin{array}{l}\text { April 30, } \\
2015\end{array}$ & 328 & 230 \\
\hline $\mathbf{2}$ & $\begin{array}{l}\text { 'From the look of things the mathematics } \\
\text { don't add up for PDP. The mathematics } \\
\text { adds up for APC.' }\end{array}$ & $\begin{array}{l}\text { February 28 } \\
2015,\end{array}$ & 375 & 263 \\
\hline $\mathbf{3}$ & $\begin{array}{l}\text { 'We make no apologies for saying } \\
\text { that government must have direct } \\
\text { intervention on poverty.' }\end{array}$ & $\begin{array}{l}\text { March 16, } \\
2015\end{array}$ & 131 & 92 \\
\hline $\mathbf{4}$ & $\begin{array}{l}\text { 'I think some of these things are creation } \\
\text { by people for one interest or the other.' } \\
\text { - Pres. Jonathan \#MediaChat }\end{array}$ & $\begin{array}{l}\text { February 11, } \\
2015\end{array}$ & 225 & 158 \\
\hline $\mathbf{5}$ & $\begin{array}{l}\text { Photo of Buhari arriving at Chatham } \\
\text { House for today's talk. }\end{array}$ & $\begin{array}{l}\text { February 26, } \\
2015\end{array}$ & 1,743 & 1,220 \\
\hline
\end{tabular}

(Author's survey, 2015)

Table 6 shows five selected posts by Sahara Reporters. Of the first 200 comments, 90\% disagreed with the position of PDP governors on their failures during the general elections. Instead, commentators blamed the PDP for failing in their duties across the country. Only $10 \%$ of the comments supported the statement issued by PDP governors. On the second, third and fourth posts, there were over $80 \%$ of comments in favour of APC and its candidate for the presidential election. Only 20\% believed that the PDP candidate would win in the election. In some of the comments that favoured PDP, there were opposing replies and disagreement among the commentators on the various political positions and issues, which they defended. The merging of three posts on this table is deliberate, owing to the fact that youth responses to each post were inter-related.

The last post was about the issue of the APC presidential candidate's visit to Chatham House in the United Kingdom. Of the first 200 comments on this post, about $75 \%$ believed that Buhari would win the election and they campaigned for him. The remaining $22 \%$ of the comments interrogated his competence to rule Nigeria based on his eligibility to contest the election. They claimed he did not have the educational qualifications required by law. This topic attracted a round of replies from APC sympathisers in defence of their presidential candidate. From 
this trend I noticed a movement of pros and antis forming another network on the platform and defending their opinions.

Table 7

Selected posts by Nasir El-Rufai

\begin{tabular}{|l|l|l|l|c|}
\hline S/N & El-Rufai's Tweets & Date & $\begin{array}{l}\text { Total } \\
\text { number } \\
\text { of } \\
\text { replies } \\
\text { (R) }\end{array}$ & $\begin{array}{l}\text { Estimated } \\
\text { number of } \\
\text { replies by } \\
\text { youth } \\
\mathbf{( 7 0 \%} \text { of R) }\end{array}$ \\
\hline $\mathbf{1}$ & $\begin{array}{l}\text { ALERT: Just spoke to one of the INEC } \\
\text { officials in Jos and PDP has offered them } \\
\text { 200m this evening to rig the ... }\end{array}$ & $\begin{array}{l}\text { April 13, } \\
2015\end{array}$ & 52 & 36 \\
\hline $\mathbf{2}$ & $\begin{array}{l}\text { Alleged plan to destabilize PDP: APC slams } \\
\text { Metuh, offers him crash course on his new role } \\
\text { The All Progressives ... }\end{array}$ & $\begin{array}{l}\text { April 17, } \\
2015\end{array}$ & 12 & 8 \\
\hline $\mathbf{3}$ & $\begin{array}{l}\text { The regional impact of Nigeria's presidential } \\
\text { election }\end{array}$ & $\begin{array}{l}\text { April 16, } \\
2015\end{array}$ & 4 & 3 \\
\hline $\mathbf{4}$ & $\begin{array}{l}\text { The Saturday polls goes beyond Twitter. } \\
\text { You need to pick up your PVC step out of your } \\
\text { house and vote for \#Change. } \\
\text { \#ElRufai2015 \# APC }\end{array}$ & $\begin{array}{l}\text { April 6, } \\
2015\end{array}$ & 48 & 33 \\
\hline $\mathbf{5}$ & $\begin{array}{l}\text { This is one of the few days that poor } \\
\text { language, disrespectful comments } \\
\text { and uneducated abuse of } \\
\text { @elrufai bring me awesome joy \& satisfaction! }\end{array}$ & $\begin{array}{l}\text { March 28, } \\
2015\end{array}$ & 19 & 13 \\
\hline
\end{tabular}

(Author's survey, 2015)

Table 7 tweets enjoyed acceptance from the youth population, as indicated in their responses. In spite of the fact that the replies under the tweet are fewer, a substantial number of them were in support of El-Rufai regarding his stance in his tweets. Approximately $99 \%$ of replies from all his selected tweets were congratulatory and supportive. Only $1 \%$ of replies were abusive and opposed to his stance; however, they were overwhelmed by the overall support that El-Rufai enjoyed from his Twitter population. 
Table 8

Selected posts by Doyin Okupe

\begin{tabular}{|c|c|c|c|c|}
\hline $\mathrm{S} / \mathrm{N}$ & Okupe's Tweets & Date & $\begin{array}{l}\text { Total } \\
\text { number of } \\
\text { replies (R) }\end{array}$ & $\begin{array}{l}\text { Estimated } \\
\text { number of } \\
\text { replies by } \\
\text { youth } \\
\text { (70\% of R) }\end{array}$ \\
\hline 1 & $\begin{array}{l}\text { @ doyinokupe Proverbs } 2421 \mathrm{My} \\
\text { son, fear thou the LORD and the } \\
\text { king: and meddle not with them that } \\
\text { are given to change: }\end{array}$ & $\begin{array}{l}\text { March 28, } \\
2015\end{array}$ & 18 & 13 \\
\hline 2 & $\begin{array}{l}\text { APC is a strange party with a } \\
\text { strange mission. Its original leaders } \\
\text { are mainly thieves while virtually all } \\
\text { its new ... fb.me/3F8Aqw } 2 \text { uz }\end{array}$ & $\begin{array}{l}\text { March 11, } \\
2015\end{array}$ & 60 & 42 \\
\hline 3 & $\begin{array}{l}\text { At last the strife is over and the } \\
\text { battles is won. God has put a new } \\
\text { song in our mouth Hallelujah!!!! } \\
\text { Victory at last. Glory be to God. }\end{array}$ & $\begin{array}{l}\text { March 24, } \\
2015\end{array}$ & 101 & 71 \\
\hline 4 & $\begin{array}{l}\text { It has pleased the Almighty God } \\
\text { to give victory to Gen Mohammed } \\
\text { Buhari, the Presidential candidate of } \\
\text { the APC and ... fb.me/ } 6 \mathrm{wjCpUgTM}\end{array}$ & $\begin{array}{l}\text { April 2, } \\
2015\end{array}$ & 17 & 12 \\
\hline 5 & $\begin{array}{l}\text { \#WeArePDPWeWillBeBack } \\
\text { \#WeArePDPWeWillBeBack } \\
\text { \#WeArePDPWeWillBeBack }\end{array}$ & $\begin{array}{l}\text { April 21, } \\
2015\end{array}$ & 60 & 42 \\
\hline
\end{tabular}

(Author's survey, 2015)

Doyin Okupe's Twitter account (Table 8) was one of the most controversial during the elections. The youth responses to his tweets attracted the attention of various news headlines during the period of 2015 general elections. I analysed all replies to his five selected tweets and noted that $97 \%$ of replies by young people were abusive, thereby dragging the account owner to be equally abusive and defensive. This dynamic had grave implications for the popularity of the PDP presidential candidate. In fact among the $3 \%$ replies that were pro-PDP, some blamed the account owner for the defeat of PDP during the elections. The youth used this account during the election to criticise PDP and to fault its media and publicity arm for propagating hate messages, which it was claimed gave the APC candidates victory in the 2015 general election. 
Table 9

Selected posts by Rueben Abati

\begin{tabular}{|l|l|l|c|c|}
\hline S/N & Abati's Tweets & Date & $\begin{array}{l}\text { Total } \\
\text { Number of } \\
\text { Replies (R) }\end{array}$ & $\begin{array}{l}\text { Estimated } \\
\text { number of } \\
\text { replies by } \\
\text { youth } \\
\text { (70\% of R) }\end{array}$ \\
\hline 1 & $\begin{array}{l}\text { Obasanjo's unwarranted attack } \\
\text { on President Jonathan is odious, } \\
\text { repugnant and selfserving grt. } \\
\text { me/oOZgG }\end{array}$ & $\begin{array}{l}\text { Feburary 14, } \\
2015\end{array}$ & 91 & 64 \\
\hline 2 & $\begin{array}{l}\text { 'We're fully in support of } \\
\text { President Jonathan's reelection' } \\
\text { Gani Adams, State House Lagos, } \\
\text { Thurs.\#OPCfor Jonathan }\end{array}$ & $\begin{array}{l}\text { March 13, } \\
2015\end{array}$ & 74 & 52 \\
\hline 3 & $\begin{array}{l}\text { Empty APC podium at NEDG } \\
\text { 2015 Presidential Debate, Sun. } \\
\text { March 22. \#TheirBabaisMissingin } \\
\text { Action }\end{array}$ & $\begin{array}{l}\text { March 22, } \\
2015\end{array}$ & 136 & 95 \\
\hline 4 & $\begin{array}{l}\text { Jonathan's Next Four Years: My } \\
\text { vision for a Nigeria that works for } \\
\text { all.\#Must read }\end{array}$ & $\begin{array}{l}\text { March 23, } \\
2015\end{array}$ & 30 & 21 \\
\hline 5 & $\begin{array}{l}\text { Lee Kuan Yew's glowing example } \\
\text { will eternall inspire positive } \\
\text { developments in the World- } \\
\text { President Jonathan grt.me/A2tud }\end{array}$ & $\begin{array}{l}\text { March 23, } \\
2015\end{array}$ & 11 & 8 \\
\hline
\end{tabular}

(Author's survey, 2015)

Equally controversial was Abati's Twitter account (Table 9). The owner of the account is one of the media aides of the PDP presidential candidate. The youth population on this account rely on information from his tweets owing to its official nature. Of the replies I analysed, $97 \%$ comments on the five selected tweets were against Abati's stance. The teeming youth replies on the account were not demeaning, unlike those for Okupe, although they made a mockery of the tweets. Some followers bluntly affirmed the elections would be in favour of the opposition and often defended the opposition (APC) in their replies. I observed that the remaining $3 \%$ replies to the tweets were carefully made in view of the overwhelming population of youth opposition and the fear that one might be bullied on the platform, which often ended up as major news headlines on other media platforms. 
Table 10

Selected posts by Femi Fani-Kayode

\begin{tabular}{|l|l|l|l|l|}
\hline S/N & Fani-Kayode's Tweets & Dates & $\begin{array}{l}\text { Total } \\
\text { number of } \\
\text { replies (R) }\end{array}$ & $\begin{array}{l}\text { Estimated } \\
\text { number of } \\
\text { replies by } \\
\text { youth } \\
\text { (70\% of R) }\end{array}$ \\
\hline $\mathbf{1}$ & $\begin{array}{l}\text { My attention has been drawn to } \\
\text { a story that I am renting a crowd } \\
\text { to embarrass Gen. Buhari at } \\
\text { Chatham House later today. It is } \\
\text { a lie. }\end{array}$ & $\begin{array}{l}\text { February 26, } \\
\text { (2015 }\end{array}$ & 167 & 117 \\
\hline $\mathbf{2}$ & $\begin{array}{l}\text { "APC is a formation of hate, } \\
\text { anger, frustration, envy and } \\
\text { malice. They are the dregs of the } \\
\text { PDP" - Gov. Sule Lamido. }\end{array}$ & $\begin{array}{l}\text { March 15, } \\
2015\end{array}$ & 55 & 39 \\
\hline $\mathbf{3}$ & $\begin{array}{l}\text { Amaechi has alleged that Pastors } \\
\text { were paid 6 billion to campaign } \\
\text { against Buhari. What a dirty lie. } \\
\text { He has sold his soul to the devil. }\end{array}$ & $\begin{array}{l}\text { February 4, } \\
2015\end{array}$ & 185 & 130 \\
\hline $\mathbf{4}$ & $\begin{array}{l}\text { If u have run from the debate } \\
\text { simply because u can't hold ur } \\
\text { own, u committed perjury and u } \\
\text { lied about ur certificate just say } \\
\text { so. }\end{array}$ & $\begin{array}{l}\text { January 30, } \\
2015\end{array}$ & 150 & 105 \\
\hline $\mathbf{5}$ & $\begin{array}{l}\text { By God's grace we are going } \\
\text { to win this election. President } \\
\text { Jonathan belongs to the modern } \\
\text { age whilst Buhari belongs to the } \\
\text { stone-age. }\end{array}$ & $\begin{array}{l}\text { January 19, } \\
2015\end{array}$ & 185 & 130 \\
\hline
\end{tabular}

(Author's survey, 2015)

Fani-Kayode's Twitter account (Table 10) was also controversial; this account belongs to the media director for the PDP presidential candidate. The five selected tweets enjoyed scrutiny by the youth. Of the replies I studied from the selected tweets, 98\% were abusive, raw and derogatory of the opposition. At one point Fani-Kayode had abusively responded to these replies, which most times ignited rage in the youth - who also attacked him on his Twitter page. In some replies they claimed that Fani-Kayode was unprofessional in his handling of youth and information on Twitter. Only $2 \%$ of replies favoured Fani-Kayode's tweets and these were enmeshed in abusive replies. As with the previous two accounts (Tables 8 and 9), it was claimed that this account contributed to the defeat of the PDP presidential candidate. 


\section{UNDERSTANDING THE DISCOURSE}

In this study, archival posts and tweets from the selected Facebook and Twitter accounts were studied to understand the impact of the youth on the 2015 electoral process vis-à-vis their social media usage. The number of comments and replies that followed the posts and tweets, as shown in the previous section, affirm Ogunlesi's (2013) findings from a youth social media survey, in which he claimed that young people constitute $70 \%$ of active social media users in Nigeria.

Although the tables above do not show quotes of comments and replies by young people, my study painstakingly examined how youths responded to issues and situations during the elections. As shown in Tables 3 and 4, the social media population that follows the accounts of politicians and political parties does not guarantee victory in an election. Goodluck Jonathan had 1864143 Facebook likes (population), while Muhammadu Buhari had 121 949. The idea of likes and followers on Facebook and Twitter is that one must belong to these categories to be able to view and share information, comment and reply to information on any account of choice. My analysis also established that the conventional definition of 'like' - which implies affection and love - is not clearly defined on Facebook. In the same vein, the population of a Twitter account is called followers. In everyday English, 'followers' denotes supporters, fans, factions and admirers. Nigerian youth during the 2015 general elections refuted the common meanings of those words. It was noticeable that both followers and likes of accounts examined in this study comprised youth devotees and oppositions on both sides.

With reference to Tables 3 to 10, the study showed that Facebook and Twitter are sometimes used to spread false and hate messages or to intimidate and bully others. Nnanyelugo and Nwafor (2013) corroborated this in their work. My study also identified that politicians and their political parties do not have wellgrounded knowledge of Nigerian youth's social formation, and thus have fallen prey to youth's tactics of dragging politicians into using abusive and offensive language. This accounts for one of the main reasons why the hitherto ruling party (PDP) lost in the 2015 elections. Undoubtedly, Facebook and Twitter engaged the youth during the period of the elections by sharing information on electoral malpractices and insecurity.

From the presentation and analysis in Table 7, we note that the social media platform was used by El-Rufai to make security alerts on election rigging. Some young people responded to this by providing additional information through videos, pictures and audio evidence from various locations. This evidence clearly indicates there has been a shift away from previous patterns in which youths were actors in violence during elections. Social media advocacy and information are largely responsible for this drastic disinclination, thereby reducing the propensity of youths to engage in electoral violence in Nigeria. 
Among the comments and replies that followed selected posts and tweets on social media accounts examined in this study, Tables 3 to 10 list the estimated number of replies from the youth. This explains the notion of forming other networks that are different from the ones initiated by Facebook and Twitter accounts. For instance, there may be comments and replies to a post or tweet from the youth; however, once an offensive comment or reply to post or tweet is noticed, rather than following the trend of comments and replies, they form another subnetwork on the controversial comments or responses to defend, abuse, bully and campaign to express their fanatical support for the candidate of their choice. This pattern was common on all the accounts selected for this study. Furthermore, the study included other non-political Facebook accounts (Channels TV and Sahara Reporters) to which the youths took their movement as it were.

\section{CONCLUSION}

In this study I interrogated the roles played by Nigerian youth during the 2015 general elections. I started by defining Nigerian youth within the context of social media platforms Facebook and Twitter during the period of the elections. I analysed the social media evidence, with an emphasis on how young people in Nigeria utilised social media to redefine and appreciably abate Nigeria's electoral culture of violence, election rigging and disenfranchisement. The findings also showed the increasing political participation and advocacy tendencies of youth in Nigeria on Facebook and Twitter, and how this has helped to reshape their mindset on electoral violence and malpractice during the 2015 elections. This stands in contrast to past experiences, in which young people's numerical strength and access barely influenced the direction of the electoral process in Nigeria.

It would serve no purpose to wish away the significant contribution of social media platforms, especially Facebook and Twitter, to the success of the 2015 general election in Nigeria. The youth and social media platforms were also instrumental in elections conducted recently in the United Kingdom, as in other developed and developing countries. As in these other countries, Nigeria has had its share of youth and social media influence over electoral processes, though it was noticeable during the 2011 general elections but became exceptional in 2015. Above all, I therefore conclude that social media can play a potent role in galvanising the youth for political discourse, conscientisation and education. In turn, these phenomena can facilitate the effective transformation of electoral processes in Nigeria. 


\section{- REFERENCES}

Abdullahi, M 2013, 'Elections and political violence in Nigeria: past mistakes and challenges ahead.' International Journal of Advanced Legal Studies and Governance, vol. 4, no. 1, pp. 63-74.

Adibe, J 2015, 'The 2015 presidential elections in Nigeria: the issues and challenges.' The Brookings Institution, Africa Growth Initiative. https: / www.brookings.edu/ wp-content/uploads/2016/07/nigeria-elections-adibe.pdf

Aduloju, AA \& Pratt, OO 2015, 'Oil, children and adolescents in the contemporary Niger Delta, Nigeria.' Journal of Child and Adolescent Behaviour, vol. 3, no. 3, pp. 1-5.

Ary, D, Jacobs, LC \& Razavieh, A 1972, Introduction to Research in Education. New York: Holt, Rinehart and Winston, Inc.

Babbie, E 1990, Survey Research Methods (2 ${ }^{\text {nd }}$ ed.). Belmont, California: Wadsworth Publishing Company.

Bamgbose, JA 2012, 'Electoral violence and Nigeria's 2011 general elections.' International Review of Social Sciences and Humanities, vol. 4, no. 1, pp. 205219.

Premium Times 2005, 'Nigeria: how Nigerians use social media' http://allafrica. com/stories/201509281392.html

Duggan, M, Ellison, NB, Lampe, C, Lenhart, A \& Madden, M. 2015, 'Social media update 2014,' Pew Research Center, http://www.pewinternet.org/2015/ 01/09/social-media-update-2014/

Duggan, M \& Smith, A 2013, Pew Research Center, 'Social media update 2013'. http:/ / pewinternet.org/Reports/2013/Social-Media-Update.aspx

Fasakin, A 2015, 'State and democratization in Nigeria.' Democracy and Security, vol. 11, no. 3, pp. 298-317.

Gambo H 2015, "“We have a few questions for you!" EnoughisEnough Nigeria to host Cross River's first youth-focused governorship debate.' http:// ynaija.com/we-have-a-few-questions-for-our-next-chief-public-servant-enough-isenough-nigeria-to-host-cross-rivers-first-youth-focused-gubernatorial-debate /

Gary, TH 1990, Practical Sampling. Newbury Park, California: Sage Publications.

Halliru, T 2013, 'Political violence and youth gangs in Bauchi State, Nigeria.' Journal of Research in National Development, vol. 11. no. 2.

Inokoba, PK \& Maliki, AE 2011, 'Youths, electoral violence and democratic consolidation in Nigeria: the Bayelsa State experience.' Anthropologist, vol.13, no. 3, pp. 217-225.

Jones, HL 1955, 'The application of sampling procedures to business operations.' Journal of the American Statistical Association, vol. 50. no. 271, pp. 763-774. 
Mayfield, A 2006, 'What is social media?' http://www.repromax.com/docs/ 113/854427515.pdf

Obi, C 2006, Youth and the generational dimension to struggles for resource control in the Niger Delta: prospects for the nation state project in Nigeria. Dakar, Senegal: CODESRIA.

Ogunlesi, T 2013, 'Youth and social media in Nigeria.' http://www.rjr.ru.ac.za/ rjrpdf/rjr_no33/Youth_and_Social_media_in_Nigeria.pdf

Okoro, N \& Nwafor, KA 2013, 'Social media and political participation in Nigeria during the 2011 general elections: the lapses and the lessons.' Global Journal of Arts Humanities and Social Sciences, vol. 1, no. 3, pp. 29-46.

Omede, AJ \& Bakare, AR 2014, 'The impact of civil society organizations on sustainable development in developing countries: the Nigerian experience.' African Research Review, vol. 8, no. 1, pp. 205-227.

Pescosolido, BA 1991, 'The sociology of the professions and the profession of sociology: professional responsibility, teaching, and graduate training.' Teaching Sociology, vol. 19, pp. 351-361.

Pescosolido, BA 2007, 'Sociology of social networks', in D Clifton, DL Bryant \& DL Peck (eds), The Handbook of 21st Century Sociology. Thousand Oaks, California: Sage Publications.

Seal-World 2014, 'Amazing social media statistics in Nigeria - Part 1', http:/ /www. sealworld.com.ng/amazing-social-media-statistics-in-nigeria-part-1/

Thurston, A 2015, Background to Nigeria's 2015 elections. Washington, D.C.: Center for Strategic and International Studies.

Uadiale, M2011, 'The role of civil society organizations in democratic consolidation in Nigeria: the birth of a new order.' International Journal of Advanced Legal Studies and Governance, vol. 2, no. 1, pp. 152-162. 